\title{
The Results of Physical Fitness Test for Chinese College Students of Different Ethnic Groups Majoring in Physical Education
}

\author{
Fei GUO ${ }^{2 *}$, Jing $\mathrm{SONG}^{b}$ and Ai-Ping $\mathrm{CHI}^{\mathrm{c}}$
}

School of Physical Education, Shaanxi Normal University, Shaanxi Xi'an, China

a: 26277209@qq.com, b: 1729930145@qq.com, c: 381686871@qq.com

*Corresponding author

Key words: different ethnic groups; physical education; college students; physical fitness

\begin{abstract}
Objective: To illustrate the differences of body composition and athletic ability of ethnic minorities students and Han students. Methods: test the body composition and athletic ability of 112 Han and minorities college students in Shaanxi Normal University. Results: The percentage of body fat in male minority students is significantly lower than that in $\operatorname{Han}(\mathrm{P}<0.05)$. The statistic of female minority students compared with the Han had no statistical significance $(\mathrm{P}>0.05)$. Conclusion: There are some difference in physical fitness between male minority college students and male Han college students.
\end{abstract}

\section{Introduction}

It is of great significance to promote college students' physical and mental health by strengthening their physical fitness and improving students' athletic ability [1,2]. And physical fitness is the material basis for students to live and learn. Physical fitness is a basic indicator of body movement ability and physical activity ability. The physical fitness may differ from different ethnic groups [3]. Whether there are differences in physical fitness between ethnic minority of college students and Han has no corresponding reports. Therefore, this article compared body composition and athletic ability and other indicators of the ethnic minorities college students and the Han, which all major in physical education, to understand their physical differences.

\section{Methods}

\section{Objects}

This paper studied 112 college students' body composition and athletic ability. They are all from Shaanxi Normal University, major in physical education and of different ethnicity such as Han, Miao, Yao, Tibetan, and Mongol. The basic information of the students is shown in Table 1.

Table 1 Basic situation of student $(n=112)$

\begin{tabular}{|c|c|c|c|}
\hline Ethnicity & Sex & numbers & percentage \\
\hline \multirow{2}{*}{ Han } & male & 74 & $66.0 \%$ \\
\cline { 2 - 4 } & female & 21 & $18.8 \%$ \\
\hline $\begin{array}{c}\text { Ethnic } \\
\text { minorities }\end{array}$ & male & 11 & $8.9 \%$ \\
\cline { 2 - 4 } & female & 6 & $5.4 \%$ \\
\hline
\end{tabular}

\section{Determination of Body Composition}

Body composition analyzer (Made in South Korea) was used to determinate the percentage of body weight, ratio of waist and hip, basal metabolic rate and other items. 


\section{Determination of Aerobic Capacity}

Harvard step test was applied for 3 minutes each time. Height of the steps: male- $40 \mathrm{~cm}$, female- $35 \mathrm{~cm}$. the frequency go upper and lower step is 30 times / min. Record the heart rate and oxygen saturation before and after the exercise.

\section{Determination of Anaerobic Capacity}

Cycle ergometer was used. The tester had to do 10 minutes of preparation before the test. According to tester's age and weight to determine the load. The time of test is 30 seconds. Recorded the maximum anaerobic power, the average anaerobic power and other data.

\section{Statistical Aanalysis}

The t-test test was performed using GraphPad Prism5. The results were expressed as mean \pm standard deviation, with $\mathrm{P}<0.05$ indicating significant difference.

\section{Results}

\section{Results of Body Composition Test}

Students' percentage of body weight, waist to hip ratio, basal metabolism are shown in Table 2:

Table 2 Comparison of body composition

\begin{tabular}{|c|c|c|c|c|}
\hline Group & Sex & $\begin{array}{c}\text { Percentage of } \\
\text { body fat }\end{array}$ & $\begin{array}{c}\text { Ratio of waist } \\
\text { and hip }\end{array}$ & $\begin{array}{c}\text { Basal } \\
\text { metabolism }\end{array}$ \\
\hline \multirow{2}{*}{ Han } & Male & $16.72 \pm 1.27$ & $0.82 \pm 0.17$ & $1624 \pm 44.23$ \\
\cline { 2 - 5 } & Female & $23.21 \pm 1.04$ & $0.84 \pm 0.12$ & $1358 \pm 29.51$ \\
\hline Ethnic minorities & Male & $14.18 \pm 1.67^{*}$ & $0.85 \pm 0.13$ & $\begin{array}{c}1758 \pm 46.12 \\
*\end{array}$ \\
\cline { 2 - 5 } & female & $21.30 \pm 1.28$ & $0.82 \pm 0.11$ & $1388 \pm 28.84$ \\
\hline
\end{tabular}

*: Compared with male Han, $\mathrm{p}<0.05$

Table 2 shows that there is no significant difference between female Han students and minorities at body fat percentage, waist-to-hip ratio and basal metabolism between $(\mathrm{P}>0.05)$. Compared with male minority, Han's the percentage of body fat is significantly lower, while the basal metabolic rate is significantly higher $(\mathrm{P}<0.05)$.

\section{Results of Aerobic Capacity}

Students' the ability of aerobic capacity are shown in Table 3:

Table 3 Test results for students with aerobic capacity

\begin{tabular}{|l|l|l|l|l|}
\hline Group & Sex & $\begin{array}{l}\text { Heart rate } \\
\text { before exercise }\end{array}$ & $\begin{array}{l}\text { Heart rate after } \\
\text { exercise }\end{array}$ & $\begin{array}{l}\text { Oxyhemoglobin } \\
\text { saturation }\end{array}$ \\
\hline \multirow{2}{*}{ Han } & Male & $70.74 \pm 1.19$ & $146.8 \pm 1.94$ & $96.64 \pm 3.01$ \\
\cline { 2 - 5 } & Female & $81.17 \pm 6.27$ & $140.6 \pm 3.29$ & $97.50 \pm 2.43$ \\
\hline $\begin{array}{l}\text { Ethnic } \\
\text { minorities }\end{array}$ & Male & $70.18 \pm 3.79$ & $141.3 \pm 2.18$ & $97.64 \pm 2.45$ \\
\cline { 2 - 5 } & female & $81.17 \pm 6.27$ & $150.5 \pm 4.75$ & $98.50 \pm 2.43$ \\
\hline
\end{tabular}

Table 3 shows that there is no significant difference between the four groups at the heart rate, before and after exercise and oxyhemoglobin saturation. 


\section{Results of Anaerobic Capacity}

The results of students' anaerobic capacity are shown in Table 4:

Table 4 Results of anaerobic capacity

\begin{tabular}{|l|l|l|l|l|l|}
\hline Group & Sex & $\begin{array}{l}\text { Average } \\
\text { power }\end{array}$ & $\begin{array}{l}\text { The max of } \\
\text { anaerobic } \\
\text { power }\end{array}$ & $\begin{array}{l}\text { Max of } \\
\text { turns }\end{array}$ & $\begin{array}{l}\text { Time to } \\
\text { reach the } \\
\text { max power }\end{array}$ \\
\hline \multirow{2}{*}{ Han } & Male & $541.3 \pm 19.62$ & $721.0 \pm 16.68$ & $138.5 \pm 2.77$ & $8.05 \pm 0.45$ \\
\cline { 2 - 6 } & Female & $355.8 \pm 17.12$ & $440.6 \pm 23.15$ & $102.8 \pm 4.01$ & $10.84 \pm 1.51$ \\
\hline $\begin{array}{l}\text { Ethnic } \\
\text { minorities }\end{array}$ & Male & $563.1 \pm 13.97 *$ & $689.3 \pm 15.23$ & $141.1 \pm 5.49$ & $7.17 \pm 1.49$ \\
\cline { 2 - 7 } & Female & $361.0 \pm 37.69$ & $443.5 \pm 21.5$ & $98.17 \pm 6.68$ & $10.98 \pm 1.54$ \\
\hline
\end{tabular}

*: Compared with male Han students, $\mathrm{p}<0.05$

The Table 4 shows that the average power was significantly higher $(\mathrm{P}<0.05)$ in male minorities compares with male Han students, and there is no significant difference between the other indexes (such as maximum anaerobic power and time to reach the maximum power $\mathrm{P}>0.05$ ). There were no statistically significant differences between the female minorities and the female Han students (P> $0.05)$.

\section{Discussion and Conclusion}

Athletic ability refers to the ability of human to participate in sports and training, the external load that the body can bear, and the comprehensive performance of body shape, quality, function, skills and psychological ability and other factors [4,5]. The intensity of the activities of human body's functions can be represented at athletic ability. And athletic capacity includes anaerobic capacity and aerobic capacity. The measurement and evaluation of aerobic capacity and aerobic capacity of human body are of great significance to study the strength of human body and function. The level of athletic ability mainly depends on the movement of ATP conversion and supply. The higher the athletic ability, the stronger the ability to use the energy in body [6]. On the reverse, the lower the athletic ability, the weaker ability of the energy processing while movement [7].

The results showed that the percentages of body fat in male minorities were significantly lower, and their basal metabolic rate and anaerobic capacity were significantly higher than the Han ( $\mathrm{P}$ $<0.05)$; and the results of female minority and female Han had no statistically significant ( $\mathrm{P}>0.05)$. Physical education students have their own excellent expertise. Nevertheless, minorities differ from the Han in the living habits, physical activity level, diet and nutrition, which may cause the higher results of basal metabolic rate and the lower body fat percentage. Reflecting in the athletic ability, the anaerobic exercise of the average power increased significantly. In conclude, we hope that this study can provide assistance to lead the students majoring in physical education, who are in varies ethnic groups, while training and taking courses.

\section{Acknowledgement}

This work was supported by the Fundamental Research Funds for the Central Universities (GK201603122, GK201603128 and GK201603129).

\section{References}

[1] Stephen J. Loew, Nigel V. Marsh, Kenneth Watson. Symptoms of Meares-Irlen/Visual Stress Syndrome in subjects diagnosed with Chronic Fatigue Syndrome. International Journal of Clinical and Health Psychology. 14(2014) 87-92. 
[2] Malarveni Damodaran Lakshmi Priya, Arumugam Geetha. A biochemical study on the level of protein and their percentage of nitration in the hair and nail of autistic children. Clinica Chimica Acta. 412(2011)1036-1042.

[3] Maes M., Kubera M., Uytterhoeven M., et al. Increased plasma peroxides as a marker of oxidative stress in myalgic encephalomyelitis/chronic fatigue syndrome (ME/CFS). Medical Science Monitor.17(2011)11-15.

[4] Tom Kindlon. Educational Programs for Chronic Fatigue Syndrome Need to Take Cognizance of the Condition's Abnormal Response to Exercise. Archives of Physical Medicine and Rehabilitation, 92(2011)1015.

[5] Samantha Lloyd, Trudie Chalder, Hannah M. Sallis, et al., Telephone-based guided self-help for adolescents with chronic fatigue syndrome: A non-randomised cohort study. Behaviour Research and Therapy. 50(2012)304-312.

[6] Samantha Lloyd, Trudie Chalder, Hannah M. Sallis, et al., Telephone-based guided self-help for adolescents with chronic fatigue syndrome: A non-randomised cohort study. Behaviour Research and Therapy. 50(2012)304-312.

[7] Junko Kawatani, Kei Mizuno, Seishi Shiraishi, et al., Cognitive dysfunction and mental fatigue in childhood chronic fatigue syndrome-A 6-month follow-up study. Brain and Development. 33(2011)832-841. 